\title{
Design of Operational Management Information Systems for Route Licenses at the Ternate City Transportation Agency based on Android
}

\author{
Muhammad Ridha Albaar ${ }^{1}$, Akil Thalib ${ }^{2}$, M. Kasyif Gufran Umar ${ }^{3}$ \\ Manajemen Informatika \\ Akademi Ilmu Komputer (AIKOM) Ternate \\ ridha_fara13@yahoo.co.id
}

\begin{abstract}
The use of information technology in terms of providing data to support the decision-making process has made information systems an essential resource. Ternate City Transportation Agency as a Transportation Agency whose job is to process public transport data, requires an accurate and accurate information system. This study discusses data processing on route permits that are integrated with an android-based database. This research uses Research and Development research procedures. The purpose of this research is to create an information system to process land transportation route permit data and simplify the process of route permit services at the Ternate City Transportation Office so that in submitting the requirements for route permits, it can be accessed via the internet.
\end{abstract}

\section{Keywords: Information Systems, Operations, Route Licenses, Android}

\section{INTRODUCTION}

The rapid growth and development of information technology in terms of supporting an agency's operations cannot be avoided. The use of information technology in terms of providing data to support the decision-making process has made the information system as an essential resource. The existence of an appropriate information system in an agency is very supportive of the mechanism of work let alone the data that is already quite a lot as in the Department of Transportation of the City of Ternate (Dishub) as an agency whose job is to process data on public transportation, and accurate and accurate information system is needed.

Processing and presenting information at Dishub already using computers, but not yet optimal, because it uses more Word / Excel applications, so it needs to develop a programming application in the data processing. The definition of public transportation is a means of conveyance or open vehicles for people operating in cities or regions, both land and sea transportation, that have been assigned route licenses by the local Transportation Agency. Processing and presenting information at Dishub already using computers, but not yet optimal, because it uses more Word / Excel applications, so it needs to develop a programming application in the data processing.

Based on the above, the authors consider it necessary to design a Public Transportation Data Processing Information System in Ternate City Transportation Agency. In the Department of Transportation, Ternate City, there are several fields of work, one of which is the making and extension of a business permit for public transportation routes. For this reason, the writer provides a limitation of the problem, especially in the processing 
of land passenger public transport route permits.

Where transportation permits are directly related to community services to improve the process of excellent service and can create good governance in the government of Ternate City, it is necessary to develop a system that can be accessed by the people of Ternate in obtaining information about the arrangement of the transportation route permit.

\section{LITERATURE REVIEW}

The information system is a system within an organization's strategic activities of an organization and the supply of certain external parties with the necessary reports (Jogiyanto HM, 1995). An information system is a working device with resources (human, computer) coordinated to change input (data) into output or information, to achieve the goals of an organization (William Davis).

The information system is a system that provides information for management in making decisions and also for carrying out company operations, where the system is a combination of people, information technology, and standardized procedures. (https://sis.binus.ac.id/2017/09/12/).

Android is an operating system for mobile devices that includes an operating system, middleware, and applications. (Ahmad Zainuddin).

\section{RESULTS AND DISCUSSION}

Research conducted by Christian, with the title Study of Oplet Type Transport Licensing Services in Pekan Baru City in 2015-2016, the purpose of this study was to determine the cause of applets not extending route licenses and to find out the services provided by the Pekanbaru City Transportation Department.
Research conducted by Emil et al., with the title Analysis of Service Quality of Public Transportation Route Licensing, this study aims to determine the factors that cause the services provided by BPMPPT in Jepara Regency to be less than optimal and to know the impact felt by the owners of public transportation from the function of the transportation route permits that are impressed long time ago.

Research conducted by Arindra et al., with the title Evaluation of Service Performance in the Department of Transportation in Urban Public Transport, the results of this study indicate that the performance of the Department of Transportation services in the field of public transportation can be said to have been carried out following applicable regulations.

While this study using research procedures Research and Development, to develop a Route Permit Information Systems, Process R \& D was starting from the preliminary research analyzing consumer needs and then develop products to meet those needs. In the only study explores the design of the proposed system, database, and architecture layer to be used in the making of this information system.

The following are the system procedures currently underway at the Ternate City Transportation Agency:

a. Licensing Services:

1. Fill out the form provided by the Ternate City Transportation Agency.

2. Photocopy of Transport business license card.

3. Photocopy STNK.

4. Photocopy KTP. 
5. Photocopy Proof Test Books Signs of Motor Vehicles.

6. Transport Company Cover Letter.

Declaration of ownership or control of motor vehicle storage.

All data is submitted in the form of archives to the Ternate City Transportation Department official.

b. Complete Route Permit

1. Motor Vehicle Registration and Registration Form (SPPKB)

2. SPPKB Receipt.

3. Regional Levy Bill.

The Ternate City Transportation Office verifies the requirements submitted by the applicant to obtain a route permit. The applicant shall continue the application for a Route License, no later than 2 (two) days after receiving the file which is declared complete and fulfilling the requirements, by the Transportation Department. Ternate City Transportation Department conducts a physical inspection of the vehicle to be adjusted with the file that has been attached by the applicant to the Transportation Department.

The results of the physical inspection are made in the minutes of the control (BAP) and attached with a route permit recommendation from the Transportation Department. Ternate City Transportation Agency issued a proposal no later than four working days containing the fulfillment of route licenses and the fulfillment of regional user fees. All processes are stored in the form of document files and data processing that is used that is using Microsoft Word and Excel so that the data is not organized in the way of a database.

The system that runs on the Ternate City Transportation Agency :
To be able to download the Transportation Route Permit Application at the Ternate City Transportation Office, a study was made, which is a stage in the development of the following software system. The picture is used for research

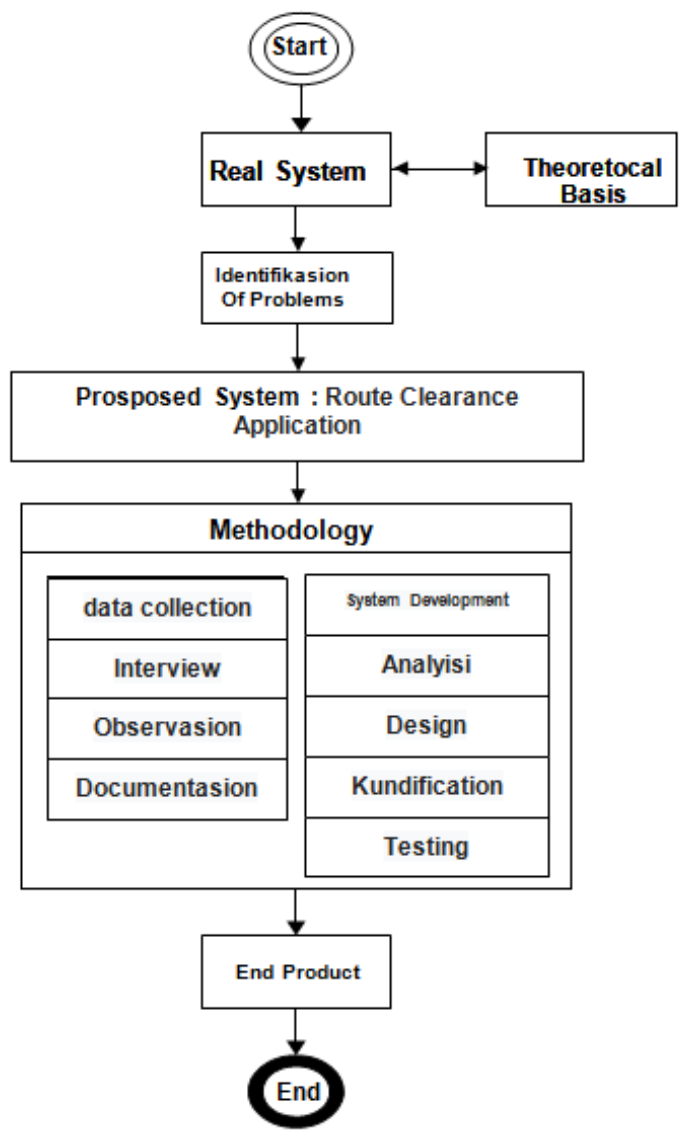

Figure 1. Research Scheme

For the sake of smoothness and convenience in the process of service to the community, it is necessary to design an application that has a database based on the website so that the general public can access it without going to the transportation department's office to see the conditions in managing route permissions so that all files needed by the community are all can be brought at the time of management so the processing can be timely and can improve the service process to the people of Ternate. So the 
authors propose a new system at the Department of Transportation of the City of Ternate as follows:

a. Licensing Services all data in the form of scanned files are stored in an image then entered in a zip file that has been prepared in the proposed system so that the applicant no longer needs the Transportation Agency because the new system is already online and makes it easy for the applicant to process the route permit and make it easier for Ternate City Transportation Department officials where the staff only need to check the system and print the report file that has been uploaded by the applicant as a complete permit for the land transportation route.

b. With the existence of this websitebased system, all of the data of the route's duplicate permits are immediately covered into the database so that there is no need to archive a lot of documents, this system automatically provides an Official Report on Examination (BAP), which if all physical inspection data is complete, enter the information for completeness of BAP, all BAPs are printed automatically, all BAPs are automatically stored in a related database starting from the process of filling out forms until the physical checking process so that within 1 (one) day the Transportation Department of Ternate can issue Route Licenses with the existence of this system to help and facilitate as well improve the performance of the Department of Transportation staff in the process of providing services to the community to create good governance.
The following is a picture of the proposed system for a land transportation route permit at the Ternate City Transportation Agency.

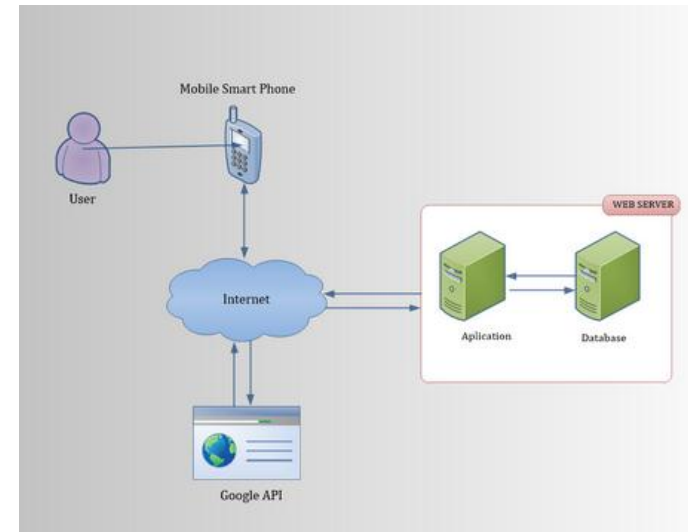

Figure 2. Proposed System

Explanation of the picture above is the user accesses using a smartphone using the internet network, then enters the application and is stored in the database.

The following is a picture of the ERD of the proposed system:

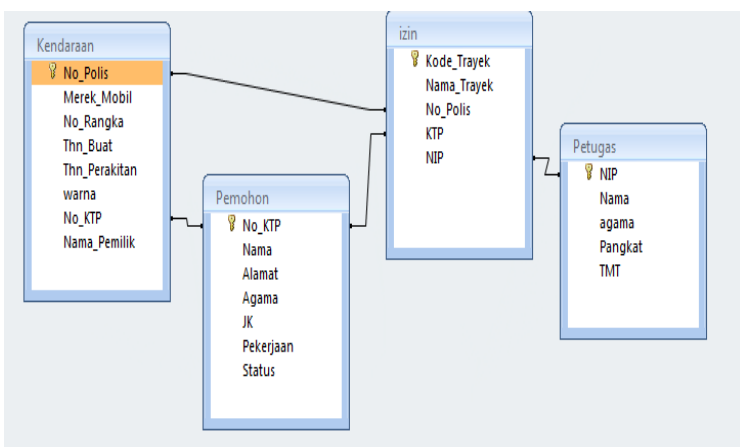

Figure 3. ERD

The following is a picture of the designed layer architecture:

Following is the user layer table of the proposed system:

Table 1. User Layer

\begin{tabular}{|r|l|}
\hline User Layer & \multicolumn{2}{|c|}{ Keterangan } \\
\hline & Applicants who will take \\
\hline
\end{tabular}




\begin{tabular}{|c|c|}
\hline User & $\begin{array}{l}\text { care of land } \\
\text { transportation route } \\
\text { permit certificates at the } \\
\text { Ternate City } \\
\text { Transportation Agency }\end{array}$ \\
\hline & $\begin{array}{l}\text { Class } 2 \text { staff of the } \\
\text { Transportation Office } \\
\text { who check on the system } \\
\text { about applicant data that } \\
\text { has made an application } \\
\text { on the Transportation } \\
\text { Department's website to } \\
\text { arrange route permits. }\end{array}$ \\
\hline Admin & $\begin{array}{l}\text { Class } 3 \text { staff who have } \\
\text { expertise in the field of } \\
\text { computers and are } \\
\text { decreed by the Head of } \\
\text { Service to manage } \\
\text { applications that exist at } \\
\text { the Transportation Office. }\end{array}$ \\
\hline & $\begin{array}{l}\text { The Head of Land } \\
\text { Transportation, whose } \\
\text { duty is to control staff in } \\
\text { the field of land } \\
\text { transportation in the } \\
\text { management of route } \\
\text { licenses, where they } \\
\text { receive reports from staff } \\
\text { after issuing route } \\
\text { licenses which will be } \\
\text { signed by the Head of the } \\
\text { Transportation Office }\end{array}$ \\
\hline Direc & $\begin{array}{l}\text { Head of Transportation } \\
\text { Department whose job is } \\
\text { to receive reports from } \\
\text { Head of Fields and } \\
\text { validate documents } \\
\text { including certificate of } \\
\text { route permits that will be } \\
\text { given to applicants who } \\
\text { will take care of land } \\
\text { transportation route } \\
\text { permits. }\end{array}$ \\
\hline
\end{tabular}

\section{CONCLUSION}

Management Information System for Data Processing of Land Transportation Route Permit at Ternate City
Transportation Department it can be concluded that:

1. This data processing system is much faster compared to data processing manually.

2. The results of data processing with this system are more precise and accurate.

3. This information system can improve the service process to the community to achieve good government.

4. This android based information system enables the driver to take care of the city of Ternate route permits so that the user uploads all data belongs

\section{ACKNOWLEDGMENT}

The Ternate City Transportation Agency supports this research work.

\section{REFERENCES}

[1] Ahmad Zainuddin, Pengenalan Android, Politeknik Elektronika Surabaya.

[2] Ajani, Safurat Toyin, (2016). "Impact of Information Communication Technology onTeaching and Learning of Business Education", Scholarly Journal of Education. Vol. 5, 2016, hal. 6, Law Reviews: www.scholarlyjournals.com/sje/archive/2016/.../pdf/A jani.p.... (diakses 3 Maret 2018)

[3] Arindra Hadi Sugianto, Sitti Rocmah, Romula Adiono, "Evaluasi Kinerja Pelayanan Dinas Perhubungan Dalam Bidang Angkutan Umum Perkotaan (Studi Pada Dinas Perhubungan Kota Malang Provinsi Jawa Timur)”, Jurnal Administrasi Publik (JAP), Vol 1, No 1.

[4] Awosejo and Kekwaletswe et al., (2013) "The Effect of Accounting Information Systems in Accounting," International Journal of Advanced Computer Research, Volume-3 Number-3 Issue-12, 2013, hal. 143, Law Reviews: http://accentsjournals.org/PaperDirecto 
ry/Journal/IJACR/.../22.pdf. (Diakses Tanggal 26 February 2018).

[5] Borg, Meredith D. Joyce P. Gall, Walter R, (2007). Educational Research an Introduction eighth edition. Boston: Pearson.

[6] Christian Hamonangan, "Studi Pelayanan Perizinan Angkutan Kota Jenis Oplet Di Kota Pekanbaru Tahun 2015-2016", JOM FISIP Vol 5 No 1April 2018.

[7] Davis Williams (1983). Systems Information: A Structured Approach, Addison-Werley Company

[8] Dimitrios at al (2013). "Traditional Teaching Methods VS Teaching Through The Application of Information And Communication Technologies In The Accounting Field: Quo Vadis?", European Scientific Journal, vol.9, No.28, 2013, page.1, Law Reviews https://eujournal.org/index.php/esj /article/ view/1885.

[9] Elsaadani, Mohamed. (2015). "Information And Communication Technology Skills' Sufficiency Of Egyptian Accounting Graduates," International Journal of Advanced Information Technology IJAIT.Vol. 5, No. 1., 2015, hal.8 Law Reviews: Http: airccse.org/journal/IJAIT/papers/5215 ijait 01.pdf. Diakses 13 Maret 2018)

[10] Emil Rifqi, Drs. Turtiantoro, Dra. Sulistiyowati, "Analisis Pelayanan Izin Trayek Angkutan Umum (Studi Badan Penanaman Modal dan Pelayanan Izin Terpadu Kota Jepara)," Jurnal Ilmu Pemerintahan 2013. www.fisipundip.ac.id

[11] Fitriati, Azmi and Sri Mulyani, (2015). "Factors That Affect Accounting Information System Success and its Implication on Accounting Information Quality." Asian Journal of Information Technology. Volume-14, Number-5, 2015, ha. 154-161. (Diakses Tanggal 26 February 2018).
[12] Goldschmid, Barbara, and Marcel L. Goldschmid, (1972). Modular Instruction In Higher Education: A Review. Montreal: McGill Univ. Center for Learning and Development, 1972.

[13] Hla, Daw, and Susan Peter Teruz (2015). "Efficiency of Accounting Information System and Performance Measures", International Journal of Multidisciplinary and Current Research, Vol.3, ISSN: 2321-3124, 2015, page. 976, Law Reviews: http://ijmcr.com. Diakses Tanggal 26 February 2018).

[14] (https://sis.binus.ac.id/2017/09/12/ apakah-sistem-informasi-itu-2/).

[15] Jogiyanto, HM, (1995). Analisis dan Desain Sistem Informasi Pendekatan Tertstruktur. Penerbit Andi Offset Yogyakarta.

[16] Wardhana W, (2014) "Rancang Bangun Aplikasi Validasi Ijin Trayek Angkutan Di Dinas Perhubungan Kabupaten Garut", ISSN : 2302-7339 $\begin{array}{lllll}\text { Vol. } & 11 & \text { No. } & 1 & 2014 .\end{array}$ Jurnal@sttgarut.ac.id 